\title{
Changes to intraocular pressure and systemic blood pressure in dogs during moderate treadmill exercise - a short communication
}

\author{
Monica Ragusa ${ }^{1}$, Michela Pugliese ${ }^{2 *}$, Angela Alibrandi ${ }^{3}$, Pietro P. Niutta ${ }^{2}$, \\ Massimo De Majo ${ }^{2}$, Rocky La Maestra ${ }^{2}$, and Annamaria Passantino ${ }^{2}$ \\ ${ }^{1}$ Department of Experimental and Clinical Medicine, University of Catanzaro, Italy \\ ${ }^{2}$ Department of Veterinary Sciences, University of Messina, Italy \\ ${ }^{3}$ Department of Economics, University of Messina, Italy
}

RAgUSA, M., M. PUGliese, A. Alibrandi, P. P. NiUTta, M. DE MAJO, R. LA MAESTRA, A. PASSANTINO: Changes to intraocular pressure and systemic blood pressure in dogs during moderate treadmill exercise - a short communication. Vet. arhiv 91, 445-450, 2021.

\section{ABSTRACT}

Physical exercise in humans induces changes in intraocular pressure, relating to the type and intensity of the workload. The purpose of the present study was to evaluate the variations in intraocular pressure and arterial blood pressure in dogs that underwent physical exercise on a treadmill. Thirty dogs were submitted to physical exercise consisting of walking (15 minutes), trotting (20 minutes), and walking (10 minutes). The intraocular pressure, blood pressure and pulse rate were recorded for each dog before starting the treadmill exercise, immediately after it ended, and after 20 minutes of passive recovery. Two-way repeated analysis of variance measurement showed the significant effect of treadmill exercise $(\mathrm{P} \leq 0.01)$ on intraocular pressure, pulse rate and diastolic blood pressure. No significant changes were observed to systolic blood pressure. Intraocular pressure and diastolic blood pressure decreased significantly during the passive recovery, and were strongly related. The pulse rate was significantly lower during the passive recovery. Although the mechanism determining the reduction in intraocular pressure during exercise remains not fully understood, our results suggest that it is strongly related to variations in arterial blood pressure.

Key words: physical exercise; eye; ocular variable; arterial blood pressure; dog

\section{Introduction}

The measurement of intraocular pressure (IOP) is a routine procedure commonly conducted during ophthalmic examinations (FEATHERSTONE and HEINRICH, 2013). It has been documented in dogs that sedative drugs (HOFMEISTER et al., 2009; GHAFFARI et al., 2010), the head and body position (KLEIN et al., 2011; PAULI et al., 2006), the circadian rhythm (GIANNETTO et al., 2009), the gender and season may influence
IOP values (GUM and MACKA, 2013). Several studies in humans have reported changes to IOP following physical exercise, relating to the type and the intensity of and proportional to the workload (RISNER et al., 2009; HONG et al., 2014; YAN et al., 2016; ESFAHANI et al., 2017). The mechanism involved in variations of IOP during exercise is not fully or clearly understood. Presumably, they are related to a complex balance of factors, such

\footnotetext{
*Corresponding author:

Dr. Michela Pugliese, Department of Veterinary Sciences, University of Messina, - Polo Universitario Annunziata, 98168 Messina, Italy, Phone: +39906766 743; E-mail: mpugliese@unime.it
} 
as neuro-hormonal activities, colloid and arterial blood pressure. Recently in veterinary medicine, the effect of the exercise on IOP has been evaluated in equine athletes during endurance competitions, but studies in dogs are limited (ALBAUGH et al., 2014). For this purpose, the authors evaluated the changes in IOP in untrained dogs that underwent physical exercise on a treadmill, correlating IOP changes with pulse rate (PR), systolic blood pressure (SBP) and diastolic blood pressure (DBP).

\section{Materials and methods}

This study was conducted at the Department of Veterinary Sciences (University of Messina), in accordance with Italian and European regulations on animal welfare, and with the approval of the Department's Ethics Committee (protocol number 2017-11).

Thirty personally owned dogs (16 males and 14 females), belonging to different breeds were included. Their median age was 2.9 y.o. $\pm 1.2 \mathrm{SD}$, and average body weight $14.1 \mathrm{Kg} \pm 2.7 \mathrm{SD}$. Written informed consent was obtained from each owner.

All the dogs were considered healthy and normotensive on the basis of a full clinical examination and arterial blood pressure measurement. Moreover, ophthalmological examinations were performed, including the Schirmer Tear Test (STT), fluorescein staining, slit-lamp biomicroscope, applanation tonometry, gonioscopy and dilated fundus examination, to rule out possible ocular abnormalities. The dogs were not pre-trained to run on a treadmill, and were not familiar with the equipment. In order to acclimatize the dogs to the procedures before the start of the study, IOP and arterial blood pressure were evaluated once a day for five days in each dog before and after exercise (PUGLIESE et al., 2019). The dogs underwent the exercise test on a motorized treadmill in the morning (professional canine treadmill, Grillo ${ }^{\circledR}$, Modena, Italy) for $45 \mathrm{~min}$. at different velocities: $2.5 \mathrm{Km} / \mathrm{h}$ for 15 minutes, $5.0 \mathrm{Km} / \mathrm{h}$ for $20 \mathrm{~min}$ and $2.5 \mathrm{Km} / \mathrm{h}$ for $10 \mathrm{~min}$. The environmental temperature was maintained at $18-21^{\circ} \mathrm{C}$, and continuously recorded. The relative humidity ranged around 50-60\%.
IOP, PR and arterial blood pressure were measured before starting the treadmill exercise (at rest) (T0), immediately after the exercise (T1), and at the end of the recovery period (T2). The IOP was recorded by applanation tonometry (TonoVet ${ }^{\circledR}$, Tiolat Ltd, Helsinki, Finland) after administration of a topical anesthetic (Oxybuprocaine Hydrochloride $0.4 \%$, Novartis Farma, Italy) by the same operator (M.R.).

For measurements of IOP, the dogs were positioned in a sternal recumbent position. During restraint, no pressure on the neck was applied. The mean value of 5 measurements at each time point was used in the calculations. The mean values of the first measurement on each day were considered the baseline values. IOP measurements were repeated in case of any excessive deviation between the 5 measurements displayed on the tonometry screen, in relation to defects in the probe position or misalignment with the central portion of the cornea.

According to the ACVIM (American College of Veterinary Internal Medicine) consensus statement (BROWN et al., 2007), a single operator (M.P.) measured the arterial blood pressure using an oscillometric device (VET HDO; S and B MedVet, Babenhausen, Germany). The dogs were acclimatized to the measurement procedure, gently restrained, and placed in lateral recumbence. The size of the cuff was selected according to the animal's limb circumference, and placed on the distal portion of the thoracic leg, between the carpal and metacarpal pads, according to the manufacturer's instructions. The first measurement was systematically discarded, and the mean values were calculated from the five consecutive measurements. The oscillometric device estimated systolic and diastolic blood pressure, as well as PR.

Statistical analysis. Statistical analyses were performed using the SPSS for Window package (Version 17.0, SPSS, Inc., Chicago, USA). The values were expressed as mean \pm standard deviation (SD). Data were analyzed by two-way repeated measures of analysis of variance (ANOVA) to compare IOP, SBP, DBP and PR values before (T0) and after exercise (T1, T2). 
Two-way repeated measurement of ANOVA was used to determine the influence of the experimental condition and different workloads on the examined indicators. Where ANOVA showed an acceptable level of significance $(\mathrm{P} \leq 0.05)$,

\section{Results}

Table 1 presents the values of IOP, SBP, DBP, and $\mathrm{PR}$ expressed as mean $\pm \mathrm{SD}$, with their conventional units. A significant decrease in IOP, PR and DBP during the passive recovery was observed. No significant differences were recorded in IOP values between $\mathrm{T} 0$ and $\mathrm{T} 1(\mathrm{P}=0.859)$. A highly significant decrease in IOP appeared between T0 and T2 $(\mathrm{P}=$ $0.000)$, and between $\mathrm{T} 1$ and $\mathrm{T} 2(\mathrm{P}=0.001)$. A nomsignificant increase in PR $(\mathrm{P}=0.590)$ was observed immediately after the end of the exercise (T1). A significant decrease in PR was present at $\mathrm{T} 2(\mathrm{P}=$ 0.0043) (Table 1).
Wilcoxon's test was applied for post hoc comparison. For all tests, a P-value $\leq$ of 0.05 was considered statistically significant, and a P-value $\leq$ of 0.01 highly significant. Spearman's coefficient was used to correlate the different factors assessed.

The increase in SBP was not statistically significant between $\mathrm{T} 0$ and $\mathrm{T} 1(\mathrm{P}=0.095)$, between $\mathrm{T} 1$ and $\mathrm{T} 2(\mathrm{P}=0.626)$ or between $\mathrm{T} 0$ and $\mathrm{T} 2(\mathrm{P}=$ 0.191) (Table 1).

Immediately after the exercise, no significant decrease in DBP values $(\mathrm{P}=0.379)$ was recorded. A highly significant decrease in DBP was observed at $\mathrm{T} 2(\mathrm{P}=0.001)$.

Spearman's rank correlation showed a significant negative correlation between IOP variations, SBP and DBP (Table 2). A positive significant correlation between SBP and PR variations was detected. The correlation between SBP and DBP was not significant (Table 2).

Table 1. Mean $\pm \mathrm{SD}$ values for intraocular pressure (IOP), systolic pressure (SBP), diastolic pressure (DBP), and pulse rate (PR) expressed in their conventional units and obtained at different times, together with the statistical significances obtained

\begin{tabular}{|l|c|c|c|}
\hline Indicators & T0 & T1 & T2 \\
\hline IOP $(\mathrm{mmHg})$ & $12.38 \pm 3.21$ & $12.29 \pm 4.26$ & $11 \pm 3.39^{* *}$ \\
\hline SBP $(\mathrm{mmHg})$ & $151.11 \pm 18.17$ & $156 \pm 18.73$ & $159.05 \pm 22.06$ \\
\hline DBP $(\mathrm{mmHg})$ & $77.11 \pm 11.34$ & $76.41 \pm 11.30$ & $71.94 \pm 14.94^{* *}$ \\
\hline PR $(\mathrm{bpm})$ & $117.41 \pm 20.34$ & $119.52 \pm 27.62$ & $110.41 \pm 26.13^{*}$ \\
\hline
\end{tabular}

$* \mathrm{P} \leq 0.05 ; * * \mathrm{P} \leq 0.01$

Table 2. Spaerman's correlation coefficients $(r)$ and significance $(\mathrm{P})$ for intraocular pressure (IOP), systolic pressure (SBP), diastolic pressure (DBP), and pulse rate (PR)

\begin{tabular}{|l|l|c|c|c|c|}
\hline & & IOP & SBP & DBP & PR \\
\hline IOP & $r$ & 1.000 & -0.442 & -0.207 & 0.035 \\
\hline & $\mathrm{P}$ & $\cdot$ & $0.000^{* *}$ & $0.040^{*}$ & 0.729 \\
\hline SBP & $r$ & -.442 & 1.000 & 0.149 & 0.267 \\
\hline & $\mathrm{P}$ & $<0.001^{* *}$ & $\cdot$ & 0.143 & $0.008^{* *}$ \\
\hline DBP & $r$ & -0.207 & 0.149 & 1.000 & -0.043 \\
\hline & $\mathrm{P}$ & $0.040^{* *}$ & 0.143 &. & -0.674 \\
\hline PR & $r$ & 0.035 & $0.267^{* *}$ & -0.043 & 1.000 \\
\hline & $\mathrm{P}$ & 0.729 & 0.008 & -0.674 &. \\
\hline
\end{tabular}

$* \mathrm{P} \leq 0.05 ; * * \mathrm{P} \leq 0.01$ 


\section{Discussion}

Aerobic exercise is currently recommended, in addition to pharmacological therapy, for lowering blood pressure levels in hypertensive and glaucomatous human patients (BHARTIYA and ICHHPUJANI, 2014). Indeed, the evidence shows that aerobic physical training promotes beneficial effects on the decrease of IOP. Physical exercise determines variations in different ocular variables, such as blood flow (OKUNO et al., 2006; POLSKA et al., 2007), tonic accommodation (HORWOOD et al., 2014), pupil size (HAYASHI et al., 2010), axial length (HONG et al., 2014; READ and COLLINS, 2011) and IOP (RISNER et al., 2009).

The first purpose of this study was to assess modifications in IOP in healthy untrained dogs, before, during, and after moderate treadmill exercise. In accordance with our results, and similar to previous observations, exercise can significantly lower IOP. However, this change is reversible and IOP returns to baseline values early after stopping exercise (HONG et al., 2014; ALBAUGH et al., 2014). A similar undulating IOP pattern (decrease, increase, decrease) was described in human patients after $15 \mathrm{~min}$ of treadmill running at a speed of $6.5-8 \mathrm{~km} / \mathrm{h}$, with an additional decrease after $30 \mathrm{~min}$ (HONG et al., 2014). Similarly, KOZOBOLIS et al. (2008) documented an IOP reduction after $1 \mathrm{~min}$ on a treadmill, although the positive effect lasted no longer than $30 \mathrm{~min}$. The change in ocular vascular blood flow seems to relate to endocrinological responses. It has been proposed that dynamic exercise may reduce the IOP by different mechanisms associated with the decrease in norepinephrine concentration, the increase in colloid osmotic pressure, and the release of nitric oxide (NO) and endothelin (ZAGO and ZANESCO, 2006; ZANESCO and ANTUNES, 2007; ALIANCY et al., 2017). The activation of the sympathetic nervous system may be involved in the changes in IOP during exercise. It has already been shown that physical training causes a sevenfold increase in circulating epinephrines in plasma (MARTIN et al., 1999).

In addressing our secondary objective, we evaluated the associations between the changes in IOP and arterial blood pressure. Our results confirm that the significant decrease in IOP is related to changes in arterial blood pressure. The significant change in BP described is suggestive of the adaptation of vascular resistance due to the vasoconstriction induced by exercise (HONG et al., 2014). Indeed, physical exercise increases SAP and PR by stimulating sympathetic activity, and maintains or decreases DAP for lower cardiac output and/or vascular resistance (QUEIROZ et al., 2018). Also, as reported in horses (ALBAUGH et al., 2014) our data do not show any correlation between variations in IOP and PR.

Similar to previous research evaluating exerciseinduced physiological changes (PICCIONE et al., 2012; PUGLIESE et al., 2019), in order to acclimatize to the facilities, all the dogs participating in the study had been previously trained on the treadmill for a period of five days. All the dogs underwent physical exercise during the morning $(8.00 / 12.00$ a.m. $)$ to rule out diurnal variations of IOP during dark hours.

Limitations of this study include the lack of functional and molecular data for the cardiovascular and ocular systems, and the absence of controltrained dogs. The oscillometric device is not considered a gold standard method for blood pressure measurement, but it can be considered a good alternative to invasive blood pressure monitoring in dogs subjected to acute exercise on a treadmill (HAMMOND et al., 2001; SALAMERCADO et al., 2013).

\section{Conclusions}

In conclusion, although the mechanism determining the reduction in intraocular pressure during exercise remains not fully understood, our results suggest that it is strongly related to the variations in arterial blood pressure. This effect is strongly related to changes in arterial blood pressure, but future studies should be considered to clarify the mechanisms involved.

\section{References}

ALBAUGH, R.A., S. M., KEIL,Z., OU, N. M.BELLO(2014): Intraocular pressure changes in equines athletes during endurance competitions. Vet. Ophtalmol. 17, 154-159. DOI: $10.1111 /$ vop. 12182 
ALIANCY, J., W. D., STAMER, B. WIROSTKO (2017): A review of nitric oxide for the treatment of glaucomatous disease. Ophtalmol. Ther. 5,

DOI: $10.1007 / \mathrm{s} 40123-017-0094-6$

BHARTIYA, S., P. ICHHPUJANI (2014): Complementary and alternate management of glaucoma: the verdict so far. J. Curr. Glaucoma Pract. 8, 54-57.

DOI: 10.5005/jp-journals-10008-1161

BROWN, S., C., ATKInS, R., BAGLEY, A., CARR, L., COWGILL, DAVIDSON, M., EGNER, B., ELLIOTT, J., HENIK, R., LABATO, M., LITTMAN, M., POLZIN, D., ROSS, L., SNYDER, P., R. STEPIEN (2007): Guidelines for the identification, evaluation, and management of systemic hypertension in dogs and cats. J. Vet. Intern. Med. 21, 542-558.

DOI: $10.1111 / \mathrm{j} .1939-1676.2007 . t b 03005 . x$

ESFAHANI, M.A., M., GHARIPOUR, H. FESHARAKINIA (2017): Changes in intraocular pressure after exercise test. Oman J. Ophthalmol. 10, 17-20.

DOI: 10.4103/0974-620X.200689

FEATHERSTONE, H. J., C. L. HEINRICH (2013): The eye examination and diagnostic procedures. In: Veterinary Ophthalmology. Ames, Iowa: John Wiley \& Sons; 533613.

GHAFFARI, M. S., M. A., REZAEI, A. H., MIRANI, N. Khorami (2010): The effects of ketamine-midazolam anesthesia on intraocular pressure in clinically normal dogs. Vet. Ophthalmol. 13, 91-93.

DOI: $10.1111 / \mathrm{j} .1463-5224.2010 .00762 . \mathrm{x}$

GIANNETTO, C., G., PICCIONE, E. GIUdiCE (2009): Daytime profile of the intraocular pressure and tear production in normal dog. Vet. Ophthalmol. 12, 302-305. DOI: 10.1111/j.1463-5224.2009.00717.x

GUM, G. G., E. O. MACKA (2013): Physiology of the eye. In: Veterinary Ophthalmology. Ames, Iowa: John Wiley \& Sons; 171-201.

HAMMOND, R. L., R. A., AUGUSTYNIAK, N. F., ROSSI, K., LAPANOWSKI, J. C., DUNBAR, D. S. O'LEARY (2001): Alteration of humoral and peripheral vascular responses during graded exercise in heart failure. J.A.P. 90, 55-61.

DOI: $10.1152 /$ jappl.2001.90.1.55

HAYASHI, N., N., SOMEYA, Y. FUKUBA (2010): Effect of intensity of dynamic exercise on pupil diameter in humans. J. Physiol. Anthropol. 29, 119-122.

DOI: $10.2114 /$ jpa2.29.119

HOFMEISTER, E. H., W. L., WEINSTEIN, D., BURGER, B. M., BRAINARD, P. J., ACCOLA, P. A. MOORE (2009): Effects of graded doses of propofol for anesthesia induction on cardiovascular parameters and intraocular pressures in normal dogs. Vet. Anaesth. Analg. 36, 442448.

DOI: $10.1111 /$ j.1467-2995.2009.00482.x
HONG, J., H., ZHANG, D. S., KUO, H., WANG, Y., HUO, D., YANG, N. WANG (2014): The short-term effects of exercise on intraocular pressure, choroidal thickness and axial length. PLoS One 29, e104294.

DOI: 10.1371/journal.pone.0104294

HORWOOD, A.M., S.S., TOOR, P.M. RIDDELL (2014): Change in convergence and accommodation after two weeks of eye exercises in typical young adults. J. A.A.P.O.S. $18,162-168$.

DOI: $10.1016 /$ j.jaapos.2013.11.008

KLEIN, A., G., SHEMESH, A., LOEWENSTEIN, S. KURTZ (2011): Intraocular pressure measurements in relation to head position and through soft contact lenses: comparison of three portable instruments. Ophthal. Surg. Las. Im. 42, 64-71.

DOI: $10.3928 / 15428877-20110120-01$

KOZOBOLIS, V. P., E. T., DETORAKIS, A. G., KONSTAS, A. K., ACHTAROPOULOS, E. D. DIAMANDIDES (2008): Retrobulbar blood flow and ophthalmic perfusion in maximum dynamic exercise. Clin. Exp. Ophthalmol. 36, 123-129.

DOI: $10.1111 /$ j.1442-9071.2007.01646.x

MARTIN, B., A., HARRIS, T., HAMMEL, V. MALINOVSKY (1999): Mechanisms of exercise-induced ocular hypotension. Invest. Ophthalmol. Vis. Sc. 40, 10111015.

DOI: 10.1016/j.pharmthera.2007.03.010

OKUNO, T., T., SUGIYAMA, M., KOHYAMA, S., KOJIMA, H., OKU, T. IKEDA (2006): Ocular blood flow changes after dynamic exercise in humans. Eye 20, 796800 .

DOI: $10.1038 /$ sj.eye.6702004

PAULI, A. M., E., BENTLEY, K. A., DIEHL, P. E. MILLER (2006): Effects of the application of neck pressure by a collar or harness on intraocular pressure in dogs. J. Am. Anim. Hosp. Assoc. 42, 207-211.

DOI: $10.5326 / 0420207$

PICCIONE, G., S., CASEllA, M., PANZERA, C., GIANNETTO, E., FAZIO (2012): Effect of moderate treadmill exercise on some physiological parameters in untrained beagle dogs. Exp. Anim. 61, 511-515.

DOI: 10.1538/expanim.61.511

POLSKA, E., C., SIMADER, G., WEIGERT, A., DOELEMEYER, J., KOLODJASCHNA, O., SCHARMANN, L. SCHMETTERER (2007): Regulation of choroidal blood flow during combined changes in intraocular pressure and arterial blood pressure. Invest. Ophthalmol. Vis. Sci. 48, 3768-3774.

DOI: $10.1167 /$ iovs.07-0307

PUGLIESE, M., M., RAGUSA, V., BIONDI, A., PASSANTINO, K., ZHANG, F. MACRI' (2019): The effect of moderate treadmill exercise on the resistive index 
of the medial long posterior ciliary artery in dogs. Vet. Med. 64, 400-406.

DOI: 10.17221/162/2018-VETMED

QUEIROZ, R. W., V. L., SILVA, D. R., ROCHA, D. S., COSTA, S. H. N., TURCO, M. T. B., SILVA, A. A., SANTOS, M. B. L., OLIVEIRA, A. S. R., PEREIRA, R. C. PALHETA-JUNIOR (2018): Changes in cardiovascular performance, biochemistry, gastric motility and muscle temperature induced by acute exercise on a treadmill in healthy military dogs. J. Anim. Physiol. Anim. Nutr. 102, 122-130.

DOI: $10.1111 /$ jpn. 12667

READ, S. A., M. J. COLLINS (2011): The short-term influence of exercise on axial length and intraocular pressure. Eye 25, 767-774.

DOI: $10.1038 /$ eye.2011.54

RISNER, D., R., EHRLICH, N. S. ,KHERADIYA, B., SIESKY, L., MCCRANOR, A. HARRIS (2009): Effects of exercise on intraocular pressure and ocular blood flow: a review. J. Glaucoma 18, 429-436.

DOI: 10.1097/IJG.0b013e31818fa5f3.
SALA-MERCADO, J. A., M. D., SPRANGER, R., ABUHAMDAH, J., KAUR, M., COUTSOS, D., STAYER, R. A., AUGUSTYNIAK, D. S. O'LEARY (2013): Attenuated muscle metaboreflex-induced increases in cardiac function in hypertension. Am. J. Physiol. Heart Circ. Physiol. 305, H1548-H1554.

DOI: 10.1152/ajpheart.00478.2013

YAN, X., M., LI, Y., SONG, J., GUO, Y., ZHAO, W., CHEN, H. ZHANG (2016): Influence of exercise on intraocular pressure, Schlemm's Canal, and the Trabecular Meshwork. Invest Ophthalmol Vis. Sci. 157, 4733-4739.

DOI: 10.4103/0974-620X.200689

ZAGO, A. S., A. ZANESCO (2006): Nitric oxide: cardiovascular disease and physical exercise. Arq. Bras. Cardiol. 81, 264-270.

DOI: $10.1590 / \mathrm{S} 0066-782 \mathrm{X} 2006001900029$

ZANESCO, A., E. ANTUNES (2007): Effects of exercise training on the cardiovascular system: pharmacological approaches. Pharmacol. Ther. 114, 307-317.

Received: 13 September 2019

Accepted: 21 April 2021

RAgUSA, M., M. PUGliese, A. Alibrandi, P. P NiUtTA, M. DE MAJO, R. LA MAestra, A. PASSANTINO: Promjene intraokularnog tlaka i sistemskog krvnog tlaka u pasa za vrijeme vježbe umjerenog intenziteta na pokretnoj traci - kratki prikaz. Vet. arhiv 91, 445-450, 2021.

\section{SAŽETAK}

Tjelesna vježba u ljudi uzrokuje promjene u intraokularnom tlaku, ovisno o vrsti i intenzitetu opterećenja. Cilj ovog istraživanja bio je procijeniti varijacije intraokularnog tlaka i arterijski krvni tlak u pasa podvrgnutih tjelesnoj aktivnosti na pokretnoj traci. Trideset pasa izloženo je tjelesnoj aktivnosti koja se sastojala od hodanja (15 minuta), trčanja u formi kasa (20 minuta) i hodanja (10 minuta). Za svakog su psa zabilježeni intraokularni tlak, krvni tlak i srčani puls prije početka aktivnosti, odmah nakon završetka aktivnosti i 20 minuta nakon oporavka. Dvosmjerna analiza varijance za ponovljena mjerenja pokazala je znakovit učinak vježbe na pokretnoj traci $(P \leq 0,01)$ na intraokularni tlak, srčani puls i dijastolički krvni tlak. Nije bilo znakovitih promjena u sistoličkom krvnom tlaku. Intraokularni tlak i dijastolički krvni tlak znakovito su se smanjili za vrijeme oporavka i bili u znatnoj korelaciji. Srčani puls bio je znakovito niži za vrijeme oporavka. Iako mehanizam koji utječe na smanjenje intraokularnog tlaka nije sasvim jasan, rezultati pokazuju da je on u čvrstoj vezi s promjenama arterijskog krvnog tlaka.

Ključne riječi: tjelesna vježba; oko; okularna varijabla; arterijski krvni tlak; pas 